\title{
POSSIBILITY OF COMBINING HIGH YIELD AND RESISTANCE TO FUSARIUM WILT DISEASE USING MOLECULAR MARKERS IN 4 ÉLITE SESAME LINES
}

\author{
Ayman Saber ANTER* and Ghada M. SAMAHA \\ National Research Centre, Field Crops Research Department, Dokki, Giza, EGYPT. \\ *Corresponding author: tokaeman@gmail.com
}

Received: 03.02.2020

\begin{abstract}
Developing a high yielding variety connected with stress-resistant in sesame is a viable option to address the adverse effects of climate change. The objectives of this study were to identify high-yielding and to detect some molecular markers associated with Fusarium wilt resistance in sesame. Five genotypes were evaluated based on seed yield ha $^{-1}$ over three growing seasons (2016-2018) at two sites, Al-Nubaria (2016-2018) and AbuHammad (2016) in Egypt. Twenty RAPD and five ISSR primers used to detect some markers linked to Fusarium wilt resistance. Genotypes and environments and interaction between them showed high significant variation $(\mathrm{p}<0.05)$ for seed yield $\mathrm{ha}^{-1}$. The mean performance of the lines $\mathrm{C1.5,} \mathrm{C3.8}, \mathrm{C6.3}$, and C1.6, for seed yield $\mathrm{ha}^{-1}$ were higher than check variety by $3.4,2.8,0.5$ and, $16.7 \%$. Line C1.6 achieved less value of the standard deviation of ranks, based on seed yield ha-1, through environments, indicating that it was less affected by environmental conditions. Molecular marker analysis revealed eight markers linked to Fusarium wilt resistance, they are seven positive markers (five RAPD and two ISSR) which were found in the line C3.8 and absent in the check variety. Finally, both C1.6 and C3.8 offering prospects to form new varieties sesame having high-yield and Fusarium wilt disease resistance.
\end{abstract}

Keywords: Climatic change, Fusarium wilt, molecular marker, sesamum indicum.

\section{INTRODUCTION}

Climate changes may contribute to biotic and abiotic stresses, which have negative impacts on global agricultural production, and the agricultural process is based on three main axes, the pathogen, and the host and the interaction with environmental conditions, where the relationships between them is the main key to the manifestation of infection, where climate changes has,among these factors, the main impact and these changes cause a decline in crop productivity (Prasch and Sonnewald, 2013; Ramegowda and Senthil-Kumar, 2015; Pandey et al., 2017; Raza et al., 2019). Plant breeding is an ideal method for facing the severe effects posed by the climate changes by creating new varieties that combine high yield and diseases resistant (Salme and Cagirgan, 2010; Lenaerts et al., 2019). Moreover, the ability of breeders to identify and access new varieties are becoming increasingly important as long as climate change continues.

In Egypt, sesame (Sesamum indicum L. ) crop has high potential as a promising crop suitable for dry areas because it needs low water requirements, adaptation to soil and weather conditions, and is also well suited to replace low-yield crops, especially under climate changes (Boureima et al., 2011; Misganaw et al., 2015; Dossa et al., 2017) and the sesame oil, other than its use as edible oil medium has specific industrial uses, make hair oil, hydrogenated oil, as well as a number of medicines. In addition, sesame seed is a good source of phosphorus, iron, magnesium, manganese, zinc and is rich in vitamin B (Suja et al., 2004; Orruno and Morgan, 2007; Quasem et al., 2009). Also, sesame may appreciably contribute to increasing the income of small farmers and plays an important role in accessing food for a lot of people by access to food and nutrition (Anilakumar et al., 2010; Baraki and Berhe, 2019). However, productivity in Egypt has been almost stagnant for a long time and Fusarium oxysporum sesame (FOS) is one of the most critical restrictions on the extension of cultivated area sesame in Egypt. This disease-causing quantitative and qualitative losses of yield (Khalifa, 2003; El-Shakhess and Khalifa, 2007; Shabana et al., 2014). Certainly, the development of high-yielding and disease resistant sesame varieties can offer permanent control over plant diseases and a low-cost and a more favorable environment and thus may partly contribute to solving the problem of oil production in Egypt. In addition, identifying the superior 
line is a key part of the plant breeding process (Boureima and Abdoua, 2019).

The combination of modern technologies in classic plant breeding programs can much change the agricultural productivity, so the practical use of the molecular marker is a significant for accurately identifying markers associated with the target trait (Kumar and Sharma, 2011; Ahmad et al., 2017; Cobb et al., 2019). And many studies of linkage analysis of wilt resistance genes showed that the resistance genes and the markers were located in at the same linkage group, they tend to stay together as each generation of plants is produced. RAPD, ISSR could be helpful for the identification of resistant genotypes and effective utilization in marker-assisted selection if it is validated on different genetic backgrounds (Maisuria et al., 2017). Many previous studies used RAPD and ISSR marker to identify markers linked to Fusarium wilt resistance in chickpea (Ratnaparkhe et al., 1998 a, b) and in rice and wheat (Prabhu et al., 2009). The objectives of this study were to identify high-yielding and to detect some molecular markers associated with Fusarium wilt resistance in elite lines of sesame.

\section{MATERIALS AND METHODS}

Plant material and experimental design

Breeding materials used in this investigation were 4 élite derived lines of sesame ( $F_{8}$ to $F_{10}$ generations) namely: C1.5, C1.6, C3.8 and C6.3. And commercial variety Shandaweel (C). These materials obtained via pedigree selection from a continuous breeding program initiated at the Agronomy Department, Faculty of Agriculture, Cairo University while $C$ brought of ministry agricultural. The characterizes of their parents and $\mathrm{C}$ presented in Table 1.

Table 1. The origin, breeding status and description for parents of lines and C.

\begin{tabular}{|c|c|c|c|}
\hline Genotypes & $\begin{array}{c}\text { Breeding } \\
\text { status }\end{array}$ & Seed source* & Specific characters \\
\hline $\begin{array}{c}\text { P1 } \\
(\mathrm{HM} 19)\end{array}$ & $\begin{array}{l}\text { F}_{8} \text {-hybrid } \\
\text { pop }\end{array}$ & Cairo Univ.* & $\begin{array}{l}\text { Early maturity, non branching, first capsule set low, } 3 \\
\text { capsules/axil, high resistant against Fusarium Oxysporum. }\end{array}$ \\
\hline $\begin{array}{c}\text { P2 } \\
\text { (EUL90) }\end{array}$ & Mutant line & Cairo Univ.* & $\begin{array}{l}\text { Early maturity, non-branching, first capsule set low, } 3 \\
\text { capsule/axil, moderate resistant against Fusarium Oxysporum. }\end{array}$ \\
\hline $\begin{array}{l}\text { P3 (Mutant } \\
\text { 48) }\end{array}$ & Mutant line & Cairo Univ.* & $\begin{array}{l}\text { Branching, } 3 \text { capsules/axil. high susceptible against Fusarium } \\
\text { Oxysporum. }\end{array}$ \\
\hline $\begin{array}{c}\text { P4 } \\
\text { (Giza 32) }\end{array}$ & $\begin{array}{l}\text { Local } \\
\text { variety }\end{array}$ & $\begin{array}{l}\text { Ministry of Agric.\& Land } \\
\text { Reclamation, } \quad \text { Egypt }\end{array}$ & $\begin{array}{l}\text { Heavy seed weight, medium branching, one capsule/axil, long } \\
\text { capsule, late maturity,moderate resistant against Fusarium } \\
\text { Oxysporum. } \\
\text { Oxysporum. }\end{array}$ \\
\hline $\begin{array}{c}\text { P5 } \\
\text { (NM59) }\end{array}$ & Exotic line & $\begin{array}{l}\text { India through } \\
\text { IAEA** }\end{array}$ & $\begin{array}{l}\text { Stiff stem, late maturity, one capsule/axil, } \\
\text { resistant against Fusarium Oxysporum }\end{array}$ \\
\hline $\begin{array}{c}\text { P6 } \\
\text { (Babil) }\end{array}$ & $\begin{array}{l}\text { Exotic } \\
\text { variety }\end{array}$ & Iraq through IAEA** & $\begin{array}{l}\text { Low branching, } 3 \text { capsules/axil, semi- } \text { shattering } \\
\text { capsules,resistant against } \\
\text { Fusarium Oxysporum . }\end{array}$ \\
\hline $\mathrm{C}$ & $\begin{array}{l}\text { Local } \\
\text { variety }\end{array}$ & $\begin{array}{l}\text { Ministry of Agric. \& Land } \\
\text { Reclamation, Egypt }\end{array}$ & $\begin{array}{l}\text { Heavy seed weight, medium branching, three capsule/axil, long } \\
\text { capsule. susceptible against Fusarium Oxysporum. }\end{array}$ \\
\hline
\end{tabular}

$*$ Advanced breeding materials resulted from the breeding program conducted at Agron. Dept. Fac. of Agric. Cairo Univ. ** International Atomic Energy Agency.

This study was complementary to another study conducted by Shabana et al.,(2014).

They were tested for their reaction against infection with either Macrophomina phaseolina, Fusarium oxysporum or their combination. Fungal inoculation of $\mathrm{M}$. phaseolina and F. oxysporum were prepared using sorghum-coarse sand-water $(2: 1: 2 \mathrm{v} / \mathrm{v})$ medium. The ingredients were mixed, bottled and autoclaved for two hours at 1.5 air pressure. The autoclaved media in glass bottles was inoculated separately using agar discs obtained from the periphery of a 5-day old colony of each of the tested fungi and incubated at $260 \mathrm{C}$ for two weeks. They were then used for soil infestation. Each fungal inoculum's was added separately or in their mixture to the sterilized potted soil at the rate of $2 \%$ by weight, mixed thoroughly with the soil surface, then watered and left for one week before sowing. Disease assessment was measured as percentages of pre- and post-emergence damping-off after 15 and 45 days from sowing, respectively. Percentages of diseased plants infected with charcoal-rot, wilt or charcoal-rot \& wilt were estimated according to a specific disease symptoms and recorded after 90 days from sowing. Charcoal-rot infection was expressed as root discoloration, black stem rot and pronounced reduction in root system of the infected plants. However, infected plants were characterized by the internal vesicular discoloration wilt appearance and might be died and fell down and then they considered wilted. They found that $\mathrm{P}_{5}$ and $\mathrm{F}_{6}$ derived lines $(\mathrm{C} 1.6, \mathrm{C} 3.8$ and $\mathrm{C} 6.3)$ were the most resistant lines against Fusarium oxysporum infection under greenhouse conditions while current study aimed to determine resistance lines based on the level genetics. 
Trials were carried out during three growing seasons (2016-2018) in two locations, first at Agricultural Production and Research Station at National Research Centre, Al-Nubaria district, El-Behera Governorate in sandy soil and sprinkler irrigation applied. Second, at Arab Zaidan Village-Abu Hammad district, AL-Sharqia Governorate for one year (2016) in clay soil (Table 2) and irrigation surface applied. Sowing dates during three seasons as follows: May 1, 10 and 13 at the Al-Nubaria site and May 8 at the AL-Sharqia site. Genotypes arranged in randomized complete blocks design with three replicates. Plots consisted of three rows, $3 \mathrm{~m}$ long and spaced $0.50 \mathrm{~m}$ apart with a $10 \mathrm{~cm}$ plant distance. Evaluation based on seed yield $\mathrm{ha}^{-1}$ : the total seed yield $\left(\mathrm{kg} / \mathrm{ha}^{-1}\right)$ harvested from the net plot area $\left(4.5 \mathrm{~m}^{2}\right)$. The recommendation of the Agricultural Ministry applied.

Table 2.Mechanical and chemical properties of the experimental soil in Al-Nubaria and AL-Sharqia sites.

\begin{tabular}{lccc}
\hline Mechanical properties & Unit & Al-Nubaria & \multicolumn{2}{c}{ AL-Sharqia } \\
\hline Coarse & $\%$ & - & 3.5 \\
Sand & $\%$ & 92.0 & 12.5 \\
Silt & $\%$ & 3.0 & 36.4 \\
Clay & $\%$ & 5.0 & 47.6 \\
Chemical properties & & & 8.03 \\
$\mathrm{PH}$ & - & 7.6 & 28.7 \\
$\mathrm{CaCo} 3$ & $\%$ & 1.42 & 0.28 \\
$\mathrm{EC}$ & $\mathrm{ds} / \mathrm{m}$ & 0.36 & 1.85 \\
Organic matter & $\%$ & 0.38 & \\
\hline
\end{tabular}

\section{Statistical analsis}

Combined analysis of variance, standard deviation (SD), and coefficient of variability (CV\%) computed by program MSTAT-C (MSTAT-C, 1991).

\section{Molecular analysis}

The lines were classified as highly resistant to Fusarium wilt at seedling and mature stages except line C1.5 (Shabana et al.10). So, according to their resistance, the C3.8 line was chosen as the highest resistant one, while $\mathrm{C}$ was chosen as the susceptible one to Fusarium wilt.

\section{Genomic DNA extraction}

Genomic DNA was extracted from genotypes using DNeasy Plant Mini Kit (Qiagen) according to the manufacturer's instructions. The DNA isolated was checked on a $1 \%$ agarose gel.

\section{RAPD and ISSR analysis}

A total of 25 primers (20 RAPD and 5 ISSR) were used in PCR amplification were synthesized by Sigma Aldrich, India. PCR reactions were performed according to (Williams et al., 1990) in DNA thermal cycler. The reaction mixture $(25 \mu \mathrm{l})$ contained a $2.5 \mu \mathrm{l}$ of $10 \times$ PCR buffer, $0.5 \mu \mathrm{l}$ of dNTPs $(2.5 \mathrm{mM})$, a $2.5 \mu \mathrm{l}$ of $\mathrm{MgCl}_{2}(2.5 \mathrm{mM}), 2.0 \mu \mathrm{l}$ of primer (RAPD and ISSR, respectively), $1 \mathrm{U}$ of Taq DNA polymerase enzyme (Fermentas) and $2 \mu \mathrm{l}$ of DNA template. The PCR reactions were performed for both methods under following conditions: initial denaturation at $94{ }^{\circ} \mathrm{C}$ for $4 \mathrm{~min} ; 35$ cycles of $1 \mathrm{~min}$ denaturation at $94{ }^{\circ} \mathrm{C}$; $1 \mathrm{~min}$ annealing at a temperature specific to the primer and extension primer at $72{ }^{\circ} \mathrm{C}$ for $2 \mathrm{~min}$ and $10 \mathrm{~min}$ at $72{ }^{\circ} \mathrm{C}$ for the final product extension. The amplification product was separated by electrophoresis on agarose $(1.5 \%)$ in $1 \times \mathrm{TBE}$ buffer run for one hour at $100 \mathrm{~V}$ and stained with ethidium bromide. The DNA bands in the gel were observed under UV transilluminator filter. The bands were photographed using a digital camera. Solis BioDyne 100 bp DNA Ladder (100-3000 bp) was used as a size markers.

\section{Data analysis}

Amplified fragments were considered as a binary character for the present (scored 1) and absent (Scored 0) using Total lab TL 120. Similarities were estimated by Jaccard's coefficient. Cluster analysis was carried out with NTSYS-pc software, UPGMA algorithm (Rohlf, 2000).

\section{RESULTS}

\section{Variance estimation and mean performance}

Combined analysis for seed yield $\mathrm{ha}^{-1}$ across environments showed significant $(p<0.05)$ difference for genotypes and environments and genotype by environment interaction $(\mathrm{G} \times \mathrm{Y})$. The data in Table 3 revealed that the mean performance of the lines $\mathrm{C} 1.5$, C3.8, C6.3, and C1.6 for seed yield ha $^{-1}$ was higher than $\mathrm{C}$ by $3.4,2.8,0.5$ and $16.7 \%$. Seed yield $\mathrm{ha}^{-1}$,on average, varied from $947.3 \mathrm{~kg}$ (C) to $1105.2 \mathrm{~kg}$ (C1.6). A high seed yield $\mathrm{ha}^{-1}$ across environments was obtained by $\mathrm{C} 1.6$ compared with overall other genotypes. The genotypes ranked based on seed yield $\mathrm{ha}^{-1}$ across environments to determine which genotypes most affected by environmental conditions (Table 4). Line C1.6 achieved the highest rank and achieved the lowest value of SD of the ranks compared to other genotypes. 
Table 3. Combined analysis and mean performance of genotypes sesame lines for seed yield ha ${ }^{-1}$.

\begin{tabular}{|c|c|c|c|c|c|c|c|c|}
\hline & & & & $\mathbf{A}$ & B & & & \\
\hline S.V. & DF & Mse & $\mathbf{G}$ & $\mathrm{F}_{8}$ & F8 & F9 & $\mathbf{F}_{10}$ & $\overline{\mathbf{x}}$ \\
\hline $\mathrm{E}$ & 3 & $135474.6 * *$ & $\mathrm{C}$ & 1505.6 & 552.0 & 853.3 & 878.4 & 947.3 \\
\hline $\mathrm{G}$ & 4 & $87478.2 * *$ & $\mathrm{C} 1.5$ & 1784.8 & 892.4 & 593.4 & 646.8 & 979.3 \\
\hline \multirow[t]{5}{*}{$\mathrm{G} * \mathrm{E}$} & 12 & $86742.2 * *$ & C 3.8 & 1449.0 & 558.9 & 1078.7 & 808.5 & 973.8 \\
\hline & & & C6.3 & 1046.5 & 632.5 & 1064.9 & 1063.8 & 951.9 \\
\hline & & & C1.6 & 1851.5 & 614.1 & 920.0 & 1035.0 & 1105.2 \\
\hline & & & $\mathrm{SD}$ & 319.8 & 139.9 & 197.3 & 171.1 & - \\
\hline & & & CV\% & 8.0 & 17.0 & 19.0 & 17.0 & - \\
\hline
\end{tabular}

S.V.: source of variance, DF: dgree of freedom, Mse: mean square, G: genotypes, A: AL-Sharqia, B: AL-Nubria, F: filial generation, $\overline{\mathrm{x}}$ : mean performance of lines, SD: standard deviation, CV\%: coefficient of variability, $* * P<0.05$

Table 4. The standard deviation of rank (SD) of genotypes for seed yield ha ${ }^{-1}$ in three generations.

\begin{tabular}{|c|c|c|c|c|c|}
\hline \multirow[b]{2}{*}{ Genotypes } & \multicolumn{4}{|c|}{ Generations } & \multirow[b]{2}{*}{ SD } \\
\hline & $\mathbf{F}_{8}$ & $\mathbf{F}_{8}$ & $\mathbf{F}_{9}$ & $\mathbf{F}_{10}$ & \\
\hline & $\mathrm{A}$ & \multicolumn{2}{|c|}{ B } & & \\
\hline $\mathrm{C}$ & 3 & 5 & 4 & 3 & 0.96 \\
\hline $\mathrm{C} 1.5$ & 2 & 1 & 5 & 5 & 2.06 \\
\hline $\mathrm{C} 3.8$ & 4 & 4 & 1 & 4 & 1.50 \\
\hline C6.3 & 5 & 2 & 2 & 1 & 1.73 \\
\hline C1.6 & 1 & 3 & 3 & 2 & 0.95 \\
\hline
\end{tabular}

A: AL-Sharqia, B: AL-Nubria, SD: standard deviation

\section{Molecular analysis}

RAPD and ISSR techniques were used to detect markers linked to Fusarium wilt resistance and determine the genetic relationships among the genotypes under study. The lines were classified as highly resistant to Fusarium wilt at seedling and mature stages except line C1.5 (Shabana et al., 2014). So, according to their resistance, the C3.8 line was chosen as the highest resistant one, while $\mathrm{C}$ was chosen as the susceptible one to Fusarium wilt.

\section{RAPD analysis}

Of the twenty RAPD primers used seven primers revealed a polymorphism, which only three developed markers linked to Fusarium wilt resistance as shown in Fig. 1 and summarized in Table 5.

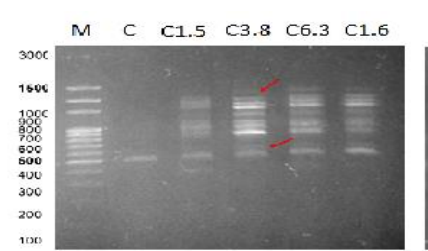

OP-A10

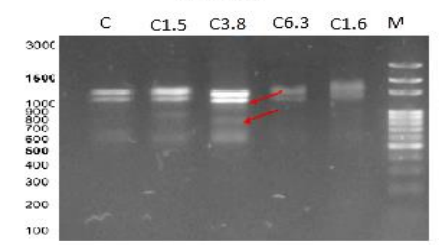

OP-O4

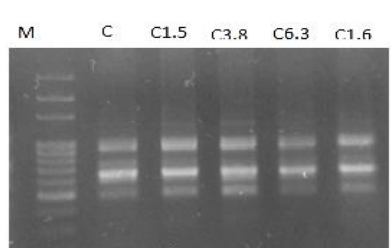

OP-A11

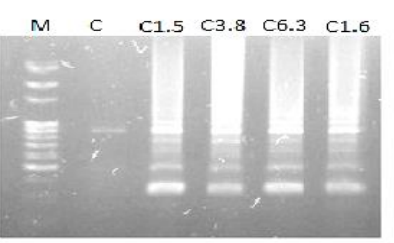

OP-D10

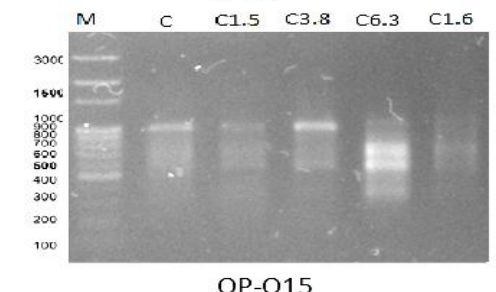

OP-O15

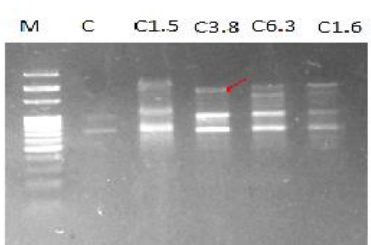

OP-B05

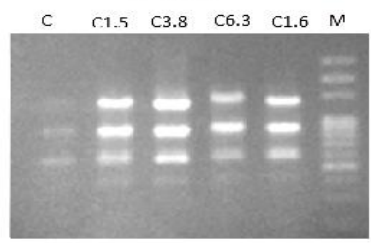

OP-B18

Fig. 1. Banding patterns of RAPD fragments of the five tested sesame (M= Marker, C, C1.5, C3.8, C6. 3 and C1.6). 
Table 5. RAPD markers and its amplification results.

\begin{tabular}{llllllll}
\hline Primer name & TB & PB & P\% & MS & MT & Size range & Primer \\
\hline OP-A10 & 9 & 8 & 88.90 & 2672 & $\mathrm{P}$ & $571-2672$ & OP-A10 \\
OP-A11 & 5 & 2 & 40.00 & - & - & $402-1268$ & OP-A11 \\
OP-B05 & 5 & 2 & 60.00 & 2036 & $\mathrm{P}$ & $767-2140$ & OP-B05 \\
OP-B18 & 5 & 2 & 40.00 & - & - & $454-1723$ & OP-B18 \\
OP-D10 & 6 & 5 & 83.33 & - & - & $311-1217$ & OP-D10 \\
OP-O04 & 7 & 2 & 85.71 & 1231 & $\mathrm{P}$ & $600-1634$ & OP-O04 \\
$\begin{array}{l}\text { OP-O15 } \\
\text { Total }\end{array}$ & 4 & 0 & 25.00 & - & - & $379-1041$ & OP-O15 \\
\hline $\begin{array}{l}\text { TB: total number of bands, PB: polymorphic bands, \%P: \% polymorphism, MS=molecular sizMT=marker type, P= Positive marker, N= negative } \\
\text { marker. }\end{array}$
\end{tabular}

OP-A10, OP-B05, and OP-O04 primers exhibited five positive markers with molecular sizes of $2672 \mathrm{bp}, 652 \mathrm{bp}$ for OP-A10, $2036 \mathrm{bp}$ for OP-B05 and $1231 \mathrm{bp}, 865 \mathrm{bp}$ for OP-O04 which were found in the line $\mathrm{C} 3.8$, while they were absent in C. RAPD markers were revealed 41 bands of which $21(51.2 \%)$ polymorphic bands. The number of bands varied from 4 (for the OP-O15) to 9 (for the OPA10 primers), ranging in size from 311 to $2672 \mathrm{bp}$. The polymorphism percentages were ranged from $25 \%$ (for the OP-O15) to $88.9 \%$ (for the OP-A10) with an average of $60.42 \%$.

The genetic similarity coefficient varied from 0.58 between $\mathrm{C} 3.8$ and $\mathrm{C}$ to 0.92 between $\mathrm{C} 1.6$ and $\mathrm{C} 6.3$ (Table 6).
Table 6. The genetic similarity matrix of the five samples based on RAPD markers.

\begin{tabular}{llllll} 
Genotypes & C & C1.5 & C3.8 & C6.3 & C1.6 \\
\hline C & 1 & & & & \\
C1.5 & 0.66 & 1 & & & \\
C3.8 & 0.58 & 0.865 & 1 & & \\
C6.3 & 0.60 & 0.84 & 0.89 & 1 & \\
C1.6 & 0.61 & 0.82 & 0.87 & 0.92 & 1 \\
\hline
\end{tabular}

The constructed dendrogram obtained by UPGMA analysis divided these samples into two main clusters (Fig. 2).

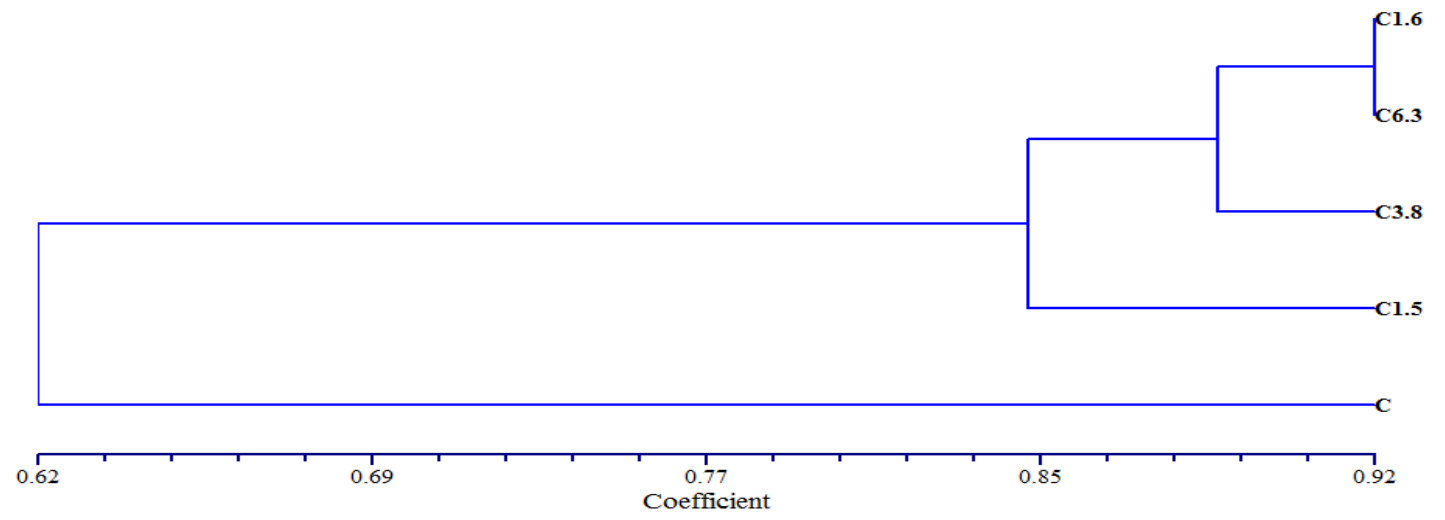

Fig. 2. UPGMA dendrograms of the five samples based on the genetic similarity matrix obtained with the Jaccard's index for the data from RAPD markers.

The first one included only C. The other cluster was divided into two main sub-clusters; the first one included only $\mathrm{C} 1.5$, while the other one was divided into two subsub clusters, the first one included only C3.8, while the second one included C1.6 and C6.3. According to RAPD analysis, these results indicated that the most closely related samples C1.6 and C6.3, which were located in the same sub-sub cluster, while the most dissimilar samples were $\mathrm{C} 3.8$ and $\mathrm{C}$.

\section{ISSR analysis}

The five ISSR primers revealed a polymorphism, only two primers developed markers linked to Fusarium wilt resistance as shown in Fig. 3 and summarized in Table 7. 


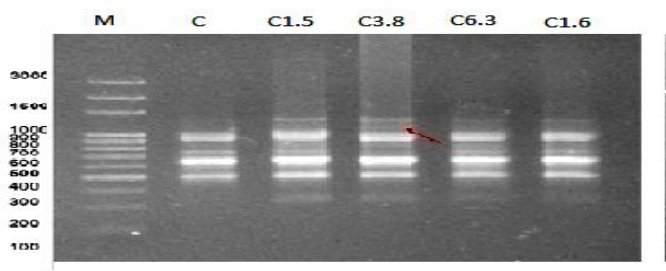

UBC 825

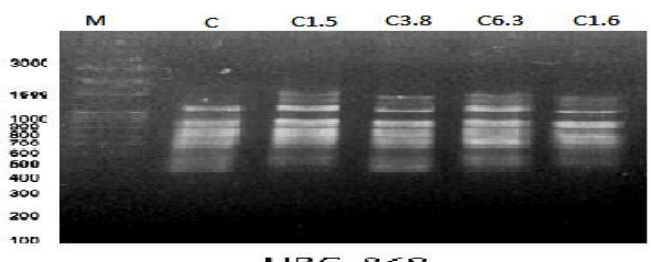

UBC 868

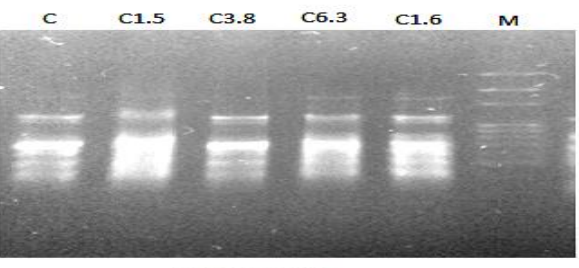

UBC 811

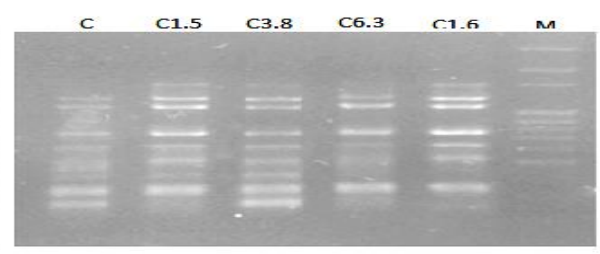

UBC 864

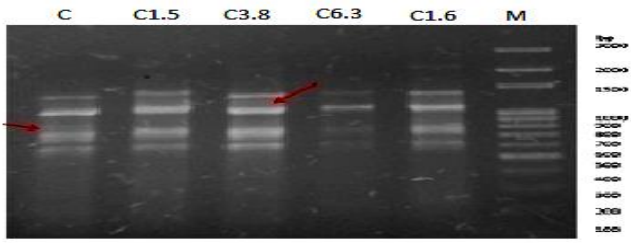

UBC 835

Fig. 3. Banding patterns of ISSR fragments of the five tested sesame (M= Marker, C, C1.5, C3.8, C6. 3 and C1.6).

Table 7. ISSR markers and its amplification results.

\begin{tabular}{cllllll}
\hline Primer name & TB & PB & P\% & MS & MT & Size range \\
\hline UBC-811 & 10 & 4 & 50.00 & - & - & $483-1715$ \\
UBC-825 & 10 & 3 & 40.00 & 1159 & P & $311-1284$ \\
UBC-855 & 8 & 1 & 62.50 & 1242 & P & $574-2121$ \\
UBC-864 & 9 & 3 & 33.33 & - & N & $-293-1593$ \\
UBC-868 & 8 & 4 & 50.00 & - & - & $371-1301$ \\
Total & 45 & 15 & & & 3 & \\
\hline
\end{tabular}

TB: total number of bands, PB: polymorphic bands, \%P: \% polymorphism, MS:molecular size, MT:marker type P: Positive marker, $\quad$ N= negative marker.

UBC-825 primer exhibited one positive marker linked to resistance with molecular sizes of $1159 \mathrm{bp}$ as well as UBC-855 primer exhibited one positive marker with molecular sizes of $1242 \mathrm{bp}$ linked to resistance were found in line $\mathrm{C} 3.8$ and one negative marker linked to $\mathrm{C}$ with molecular sizes of $801 \mathrm{bp}$. A total of 45 bands were produced of which $15(33.33 \%)$ polymorphic bands. The number of ISSR bands varied from 8 (for two primers UBC-855 and UBC-868) to10 (for two primers UBC-811 and UBC-825), ranging in size from 293 to $2121 \mathrm{bp}$. The polymorphism percentages were ranged from $33.33 \%$ (for the UBC-864) to $62.50 \%$ (for the UBC-855) with an average of $47.17 \%$.

The genetic similarity coefficient varied from 0.78 between $\mathrm{C}$ and $\mathrm{C} 1.5$ to 0.95 between $\mathrm{C} 1.6$ and $\mathrm{C} 6.3$ (Table 8).
Table 8. The genetic similarity matrix of the five samples based on ISSR

\begin{tabular}{llllll}
\hline Genotypes & C & C1.5 & C3.8 & C6.3 & C1.6 \\
\hline C & 1 & & & & \\
C1.5 & 0.78 & 1 & & & \\
C3.8 & 0.87 & 0.87 & 1 & & \\
C6.3 & 0.85 & 0.85 & 0.90 & 1 & \\
C1.6 & 0.81 & 0.87 & 0.89 & 0.95 & 1 \\
\hline
\end{tabular}

The dendrogram constructed from ISSR analysis (Fig. 4) was similar to the RAPD dendrogram. These results indicated that the most closely related samples were $\mathrm{C} 1.6$ and C6.3, while the most dissimilar samples were $\mathrm{C}$ and $\mathrm{C} 1.5$ which located in the two different main clusters. 


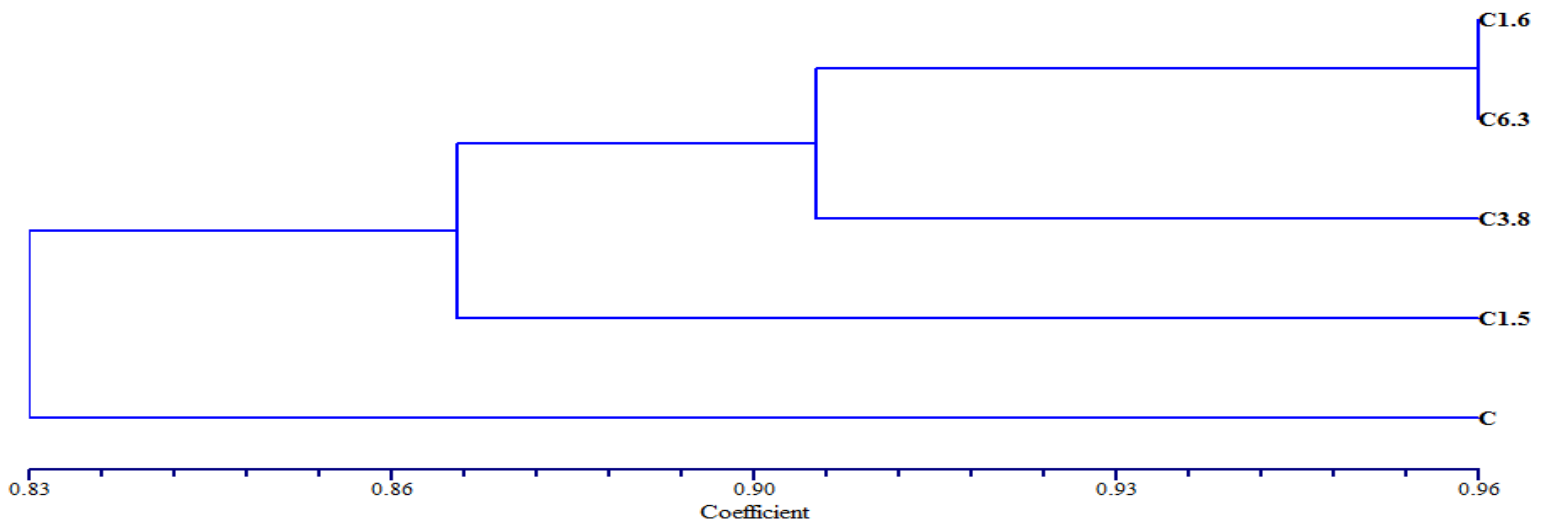

Fig. 4. UPGMA dendrograms of the five samples based on the genetic similarity matrix obtained with the Jaccard's index for the data from ISSR markers.

\section{Combination of RAPD + ISSR analysis}

The genetic similarity coefficient varied from 0.72 between $\mathrm{C}$ and $\mathrm{C} 1.6$ to 0.94 between $\mathrm{C} 1.6$ and $\mathrm{C} 6.3$ (Table 9). The RAPD and ISSR data were also combined for UPGMA cluster analysis (Fig. 5). The dendrogram was similar to the RAPD and ISSR dendrograms. According to these results, the most closely related samples were $\mathrm{C} 1.6$ and $\mathrm{C} 6.3$, while $\mathrm{C}$ and $\mathrm{C} 1.6$ were the most genetically distant.
Table 9. The genetic similarity matrix of the five samples based on RAPD + ISSR markers.

\begin{tabular}{llllll}
\hline Genotypes & C & C1.5 & C3.8 & C6.3 & C1.6 \\
\hline C & 1 & & & & \\
C1.5 & 0.73 & 1 & & & \\
C3.8 & 0.75 & 0.86 & 1 & & \\
C6.3 & 0.74 & 0.85 & 0.90 & 1 & \\
C1.6 & 0.72 & 0.85 & 0.88 & 0.94 & 1 \\
\hline
\end{tabular}

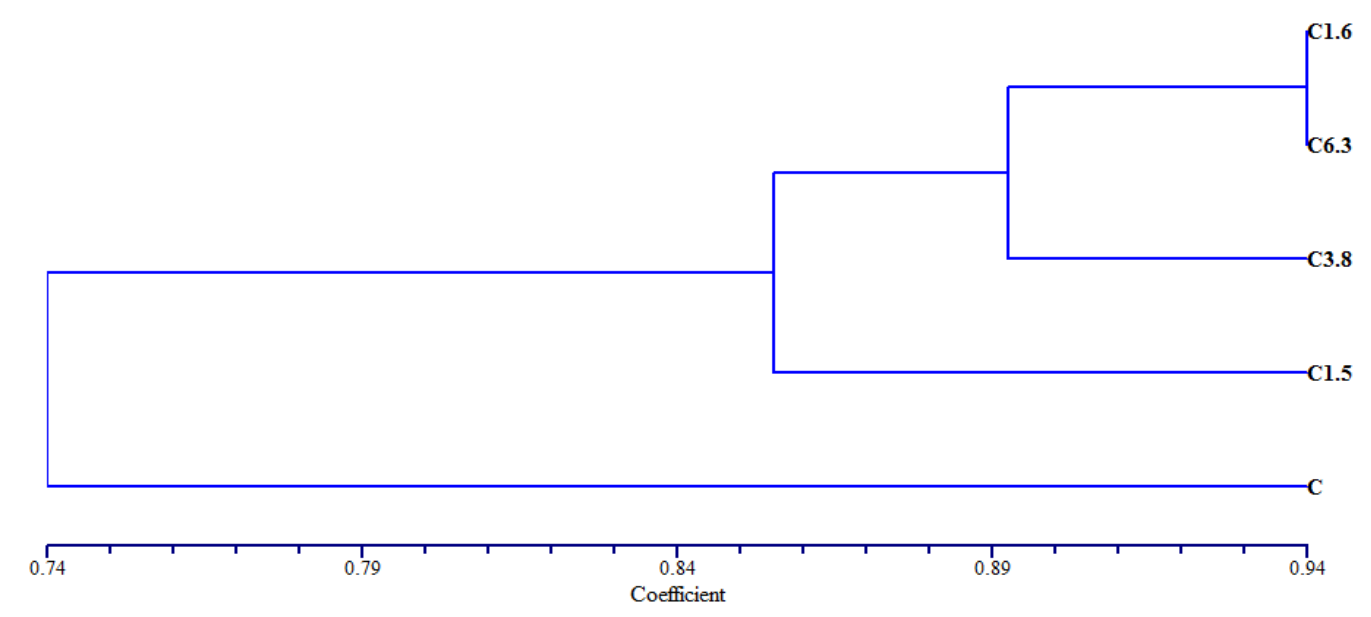

Fig. 5 UPGMA dendrograms of the five samples based on the genetic similarity matrix obtained with the Jaccard's index for the data from RAPD+ISSR markers.

\section{DISCUSSION}

\section{Variance and Mean performance}

One of the effective ways to keep crop production under new challenges of climate change is through varieties developed by plant breeding. The high-yield and disease-resistant varieties are the most important achievements of plant breeding, which adds more arable land to world agricultural production. The breeding process consists of three phases: creates variation (one year), line fixation ( $F_{2}$ to $F_{6}$ generations), and field trials (Holbrook and Culbreath, 2007; Tillman and Gorbet, 2009; Newton et al., 2011). In this study, we have reached the phase of field trials of advanced breeding lines (completely homozygous) which usually requires two years of testing against the commercial variety. In addition, breeders have always used modern plant breeding with traditional plant breeding to make their goals quickly (Forster et al., 2014). The data in Table 3 illustrated that the response of the genotypes is irresolute and fluctuated in seed yield $\mathrm{ha}^{-1}$ across environments through the growing seasons confirmed by genotype $\mathrm{x}$ environment interaction $(\mathrm{G} \times \mathrm{Y})$. And the differences were due to both of the main and interaction effects caused different fertility of soils (clay and sandy) irrigation methods (surface and sprinkler) and differences in the 
genetic make-up of the genotypes (John et al., 2001; Hoballah et al., 2009; Ahmed and Ahmed, 2012; Baraki and Berhe, 2019). Environments represent the largest proportion of sums of squares followed by genotypes consequently, the possibility of developing new varieties for specific adaptation to each of these environments (Kebede et al., 2017; Mansour et al., 2018). The mean performance of lines for seed yield $\mathrm{ha}^{-1}$ in ALSharqia was higher than AL-Nubria, because that the clay soil is higher fertility than sandy soil proven by a high percentage of organic matter in clay soil than sandy soil (Table 2). Two lines C1.6 and C1.5 excelled in the first season in clay soil while in sandy soil line C1.5 excelled. The line C1.6 achieved the highest seed yield $\mathrm{ha}^{-1}$, on average, while the other lines and $\mathrm{C}$ were about equal.This line would have excellent gene combinations, be adapted to different environments. And many authors (Taghouti et al., 2017; Anter and Ashraf, 2018; Baraki et al., 2019) pointed out to that sesame genotypes were differences in seed yield across by changing in environments. Moreover, the result of rank for genotypes based on seed yield ha- ${ }^{-1}$ across environments in Table 4 showed that $\mathrm{C}$ and $\mathrm{C} 1.6$ were less affected by environmental conditions indicated by high rank and lower SD values (Karimizadeh et al. 2012). Apparently, line C1.6 showed a high response for seed yield $\mathrm{ha}^{-1}$ across environments and could be classified as a productive and stable genotype. This was probably due to its ability to produce secondary metabolites and stored carbon as a strategy to respond to different environments (Bennett and Wallsgrove, 1994; Harborne, 1999; Beckman, 2000; Kroymann, 2011; Li et al., 2018) so, could be used as a parent in the other breeding program to form new varieties that more fixability for tackling climatic change.

\section{Molecular analysis}

The molecular markers could be utilized to enhance conventional plant breeding strategies of disease resistance. Therefore, this study carried out for the selection of the resistant and susceptible lines to Fusarium wilt through a set of RAPD and ISSR markers to detect marker linked to Fusarium wilt resistance to enhance resistant germplasm resources for increasing yield of sesame. The extent of polymorphism in this study was ranged from 25.00 to $88.90 \%$ in the case of RAPD was greater than in of the ISSR (33.33-62.50\%). These differences in polymorphism may be due to the differences in the amount of genetic variation between the samples under the study as indicated by Poerba and Ahmad (2010). Thus, this study indicates that samples examined have high genetic variation. These results complied with Ercan et al. (2004) showed that RAPD markers revealed polymorphism level of $78 \%$ was reported in 38 accessing of sesame in Turkey and 73\% polymorphism was reported in a core collection of sesame from China by Zhang et al. (2010). RAPD markers revealed more polymorphism than ISSR markers in different plant species (Farajpour et al., 2011; Patel et al., 2016). Our results showed that the average of polymorphism revealed in ISSR markers was $47.17 \%$ was higher compared with Kim et al. (2002) in which the level of polymorphism among 75 Korean sesame genotypes was $33.0 \%$ with 14 ISSR markers. However, our results were low as compared with the $98.5 \%$ of Anitha et al. (2010) in 10 sesame varieties of Tamil Nadu. And 76.47\% of Parsaeian et al. (2011) in a study of genetic variation in sesame with 13 ISSR primers. Admas et al. (2013) detected that the polymorphism was $97.3 \%$ between six sesame genotypes. Also, Kurt and Arioglu (2018) detected polymorphism percentage ranged from $33 \%$ to $100 \%$ with an average of $68.2 \%$. This difference between our results and the previous studies may be due to the low numbers of primers used. Whilst, the use of a few primers will be sufficient when the variation between genotypes is high (Li and Midmore, 1999). Salahlou et al. (2019) have been used the same number of ISSR primers to detect genetic diversity among Macrophomina phaseolina isolates of sesame in Iran. From the previous results, it was clear that the dendrogram constructed using RAPD and ISSR markers were highly similar. The genetic similarity coefficient observed in this study, $0.58-0.92$ in the case of RAPD; $0.78-0.95$ in the case of ISSR and 0.72- 0.94 in case of pooled data of RAPD and ISSR. These results are confirmed by Dar et al. (2017) reported that the similarity coefficient of RAPD ranged from 0.51 to 0.88 , and ranged from 0.34 to 0.89 between 15 sesame accessions by Quenum and Yan (2017). Whilst, our results were high compared with previous studies by Parsaeian et al. (2011) in which the coefficient of similarities ranged from 0.09 to 0.55 . In this study, we found five positive RAPD markers (OP-A $10_{2672} \&{ }_{652}$; OP$\mathrm{B} 05_{2036}$, and $\mathrm{OP}-\mathrm{O} 04_{1231} \&$ 865) and two positive ISSR markers (UBC-825 1159 and UBC-855 1242 ) and one negative marker (UBC-855 801 ) linked to Fusarium wilt resistance. The obtained results were in a good line with those obtained by Singh et al. (2011) used RAPD molecular markers in finding markers linked to Fusarium wilt resistance gene in castor bean and found three RAPD markers (RKC 231375, RKC 211080 and OPBE 18900) linked to the resistance genes. Haji-Allahverdipoor et al. (2011) found three ISSR markers (864400, UBC-811 1250 and UBC-811650) in chickpea. And Maisuria et al. (2017) found three markers (CS-27 700 , UBC-825 1200 , and UBC$\left.170_{500}\right)$ in chickpea. In general, the results indicated that the four lines of sesame, on avarge, surpassed $C$ in seed yield $\mathrm{ha}^{-1}$. Besides, these lines characterized by high resistance to Fusarium wilt except line C1.5 (Shabana et al., 2014).

\section{CONCLUSIONS}

The study concluded, from the results into that sesame genotypes significantly differ $\quad(\mathrm{P}<0.05)$ across environments, where the differences were due to both of the main and interaction effects and environments contribute to a high proportion of variation, followed by genotypes, and thus the ability to develop new varieties that adapt to each of these environments. Line C1.6 achieved the highest seed yield $\mathrm{ha}^{-1}$, on average, compared 
to check variety also, it achieved less value of the standard deviation of ranks through environments. According to molecular marker analysis. RAPD and ISSR markers revealed seven positive markers linked to Fusarium wilt resistance found in C3.8. And, one negative marker linked to Fusarium wilt resistance found in $\mathrm{C}$ therefore, which could be considered as reliable markers for Fusarium wilt resistance in sesame.Therefore, it is possible to combine the high- yielding and Fusarium wilt resistance in sesame.

\section{ACKNOWLEDGMENT}

Many thanks to the National Research Center, Egypt for funding this study.

\section{LITERATURE CITED}

Admas, A., P. Yohannes and K. Tesfaye. 2013. Genetic distance of sesame (Sesamum indicum L.) varietys and varieties from Northwestern Ethiopia using inter simple sequence repeat markers. East Afric. J. Sci. 7:31-40.

Ahmad, F., A. Akram, K. Farman, T. Abbas, A. Bibi, S. Khalid, and M. Waseem. 2017. Molecular markers and markerassisted plant breeding: Current status and their applications in agricultural development. J. of Envi. and Agric. Sci. 11: $35-50$.

Ahmed, M. B. S.and F. A. Ahmed. 2012. Genotype $\times$ season interaction and characters association of some sesame (Sesamum indicum L.) genotypes under rainfed conditions of Sudan,” Afric. J. Plant Sci. 6:39-42.

Anilakumar, R. K., A. Pal, F. Khanum and S. A. Bawa. 2010. Nutritional, medicinal and industrial uses of sesame (Sesamum indicum L.) seeds.Agric. Consp. Sci. Cus. 75:159168.

Anitha, B.K., N. Manivannan, P. Vindhiyavarman, C. Gopalakrishnan and K. Ganesamurthy. 2010. Molecular diversity among sesame varieties of Tamil Nadu. J. Plant Breed. 1: 447- 452.

Anter, A.S. and A.A. Ashraf. 2014. Evaluation performance of new sesame (Sesamum indicum L.) lines under normal and drought conditions. Mid. East J. Agric. Res. 7:1411-1418.

Baraki, F. and M. Berhe. 2019. Evaluating performance of sesame (Sesamum indicum L.) genotypes in different growing seasons in Northern Ethiopia. Inte. J. Agro. 1-7.

Beckman, G.H. 2000. Phenolic-storing cells: keys to programmed cell death and periderm formation in wilt disease resistance and in general defense responses in plants? Physiological and Mole. Plant Patho. 57:101-110.

Bennett, R.N. and R.M. Wallsgrove. 1994. Secondary metabolites in plant defence mechanisms. New Phy. 127:617-633.

Boureima, S. and A. Yaou. 2019. Genotype by yield $\times$ trait combination biplot approach to evaluate sesame genotypes on multiple traits basis. Turkish Journal of Field Crops.24:237-244.

Boureima, S., M. Eyletters, M. Diouf, T.A. Diop and P. Van Damme. 2011. Sensitivity of seed germination and seedling radicle growth to drought stress in sesame (Sesamum indicum L.). Res. J. Envir. Sci. 5:557-564.

Cobb, N. J., R.U. Juma, P. S.Biswas, J.D. Arbelaez, J. Rutkoski, G. Atlin, T. Hagen, M. Quinn and E. H. Ng. 2019. Enhancing the rate of genetic gain in public-sector plant breeding programs: lessons from the breeder's equation Theor. Appl. Gene. 132: 627-645.

Dar, A.A., S. Mudigunda, P.K. Mittal and N. Arumugam. 2017. Comparative assessment of genetic diversity in Sesamum indicum L. using RAPD and SSR markers. Biotech. 7: 10.

Dossa, K., D. Diouf, L.Wang, X. Wei, Y.Zhang, M. Niang, D. Fonceka, J.Yu, M. A. Mmadi, L.W. Yehouessi, B. Liao, X. Zhang and N. Cisse. 2017. The emerging oilseed crop Sesamum indicum Enters the "Omics" Era. Front. Plant Sci. 8:1-16.

El-Shakhess Samar, A.M. and M.M.A. Khalifa. 2007. Combining ability and heterosis for yield, yield components, charcoal-rot and Fusarium wilt diseases in sesame.Egypt J. Plant Breed. 11: 351-371.

Ercan, A.G., M. Taskin and K. Turgut. 2004. Analysis of genetic diversity in Turkish sesame (Sesamum indicum L.) populations using RAPD markers. Gene. Resou. Crop Evolu. 51: 599-607.

Farajpour, M., M. Ebrahimi, R. Amiri, S.A.S. Noori, S. Sanjari and R. Golzari. 2011. Study of genetic variation in yarrow using inter-simple sequence repeat (ISSR) and random amplified polymorphic DNA (RAPD) markers. Afric. J. Biotech. 10: 11137-11141.

Forster, B.P., B.J. Till, A.M.A. Ghanim and H.O.A. Huynh. 2014. Accelerated plant breeding. CAB Rev.9:3-15.

Haji-Allahverdipoor,K.,B. Bahramnejad and J. Amini. 2011. Selection of molecular markers associated with resistance to Fusarium wilt disease in chickpea (Cicer arietinum L.) using multivariate statistical techniques. Austra. J. Crop Sci. 5:1801-1809.

Harborne, J.B. 1999. Classes and functions of secondary products from plants. In:Chemicals from Plants, Perspectives on Secondary Plant Products, ed. Walton N.J. and Brown, D.E. 1-25, Imperial College Press,London.

HobAllah, A.A., A.A. Abd El-Mohsen, A.K. Abd El-Haleem and A.S.Anter. 2009. Genetic variability, for seed yield and its components in advanced segregating generations of sesame (Sesamum indicum L.). Ain shams Bulletin, Special Publication No. 6, Ain Shams Unv.

Holbrook, C.C. and A.K. Culbreath. 2007. Registration of 'Tifrunner' Peanut. J. Plant Regist. 1:124-124.

John, A., N. Subbaraman and S. Jebbaraj. 2001. Genotype by environment interaction in sesame (Sesamum indicum L.): Sesame and safflower newsletter no. 16, Institute of Sustainable Agriculture, FAO, Rome.

Karimizadeh, R., M. Mohammadi, N. Sabaghnia and M.K. Shefaza-deh. 2012. Using Huehn's nonparametric stability statistics to investigate genotype $\times$ environment interaction. Notu. Botan. Horti. Agrobot. Cluj-Napoca. 40:195-200.

Kebede, G., G. Assefa, F. Feyissa, M. Alemayehu, A. Mengistu, A. Kehaliew, K.Melese, S. Mengistu, E. Tadesse, S. Wolde and M. Abera. 2017. Genotype_environment interaction and stability analysis for dry matter yield of napier grass (Pennisetum purpureum L.) genotypes tested across diverse environments in Ethiopia. Omo Inte. J. Sci. 1: 1-14.

Khalifa, M.M.A. 2003. Pathological studies on charcoal rot disease of sesame.Ph.D. Thesis. Faculty. Agric. Zagazig Uni.295 pp.

Kim, D.H., G. Zur, Y. Danin-Poleg, S.W. Lee, K.B. Shim,C.W. Kang and Y. Kashi. 2002. Genetic relationships of sesame germplasm collection as revealed by inter-simple sequence repeats. Plant Breed. 121:259-262.

Kroymann, J. 2011. Natural diversity and adaptation in plant secondary metabolism. Curr. Opin Plant Biolog. 14:246251. 
Kumar V. and S.N. Sharma. 2011. Comparative potential of phenotypic, ISSR and SSR markers for characterization of sesame (Sesamum indicum L.) varieties from India. J. Crop Sci. Biotech. 14:163-171.

Kurt, C. and H. Arioglu. 2018. Assessment of genetic diversity among Turkish sesame (Sesamum indicum L.) genotypes using ISSR markers. Inter. J. Agric. and Envir. Res. 4:188199.

Lenaerts, B., C.Y. Bertrand, C. Collardb and M. Demontb. 2019. Improving global food security through accelerated plant breeding. Plant Sci.278:1-8.

Li, D., K. Dossa, Y. Zhang, X. Wei, L. Wang, Y. Zhang, A. Liu, R. Zhou and X. Zhang. 2018. Gwas uncovers differential genetic bases for drought and salt tolerances in sesame at the germination stage. Genes. $9: 1-19$.

Li, M. and D.J. Midmore. 1999. Estimating the genetic relationships of Chinese water chestnut (Eleocharis dulcis (Burm. f.) Hensch) cultivated in Australia, using random amplified polymorphic DNAs (RAPDs). J. Horti. Sci. Biotech. 74:224-231.

Maisuria, H.J., R.M. Patel and K.P. Suthar. 2017. Validation of molecular markers linked to Fusarium wilt resistance in Chickpea genotypes. Inter.J. Pure and Appl. Biosci. 5:254260.

Mansour, E., E.S. Moustafa, Z. A. El-Naggar, A.A. Asmaa and I. Ernesto. 2018. Grain yield stability of high-yielding barley genotypes under Egyptian conditions for enhancing resilience to climate change. Crop and Past. Sci. 69: 681690.

Misganaw, M., F. Mekbib and A. Wakjira. 2015. Genotype x environment interaction on sesame (Sesamum indicum L.) seed yield. Afric. J. Agric. Res. 10:2226-2239.

MSTAT-C, program. 1991. A software program for the design, management and analysis of agronomic research experiments. Michigan State Uni.

Newton, C., S.N. Johnson and P.J. Gregory. 2011. Implications of climate change for diseases, crop yields and food security. Euphy. 179:3-18.

Orruno, E. and M.R.A. Morgan. 2007. Purification and characterization of the $7 \mathrm{~S}$ globulin storage protein from sesame (Sesamum indicun L.). Food Chem. 100: 926-934.

Pandey, P., V. Irulappan, V. M. Bagavathiannan and M.SenthilKumar. 2017. Impact of combined abiotic and biotic stresses on plant growth and avenues for crop improvement by exploiting physio-morphological traits. Front. Plant Sci. 8, 537.

Parsaeian, M., A. Mirlohi and G. Saeidi. 2011. Study of genetic variation in sesame (Sesamum indicum L.) using agromorphological traits and ISSR markers. Russ. J. Gene 47:314-321.

Patel, D.M., R.S. Fougat, A.A. Sakure, S. Kumar, M. Kumar and J.G. Mistry.2016. Detection of genetic variation in sandalwood using various DNA markers. 3 Biotech. 6:2-11.

Poerba, Y.S. and F. Ahmad. 2010. Genetic variability among 18 varietys of cooking bananas and plantains by RAPD and ISSR markers. Biodiv. J. Biolo. Diver. 11:118-123.

Prabhu, K. V., A. K. Singh, S. H. Basavaraj, D. P. Cherukuri, A. Charpe, S. Gopala Krishnan, S. K. Gupta, M. Joseph, S. Koul, T. Mohapatra, J. K. Pallavi, D. Samsampour, A. Singh, V. K. Singh, A. Singh and V. P. Singh. 2009. Marker assisted selection for biotic stress resistance in wheat and rice. Indian J. Gene. 69: 305-314.

Prasch, C. M. and U. Sonnewald. 2013. Simultaneous application of heat, drought, and virus to Arabidopsis plants reveals significant shifts in signaling networks. Plant Physiol. 162: 1849-1866.

Quasem, J.M., A.S. Mazahreh and K. Abu-Alruz. 2009. Development of vegetable based milk from decorticated sesame (Sesamum Indicum L.). Amer. J. Appl. Sci. 6: 888896.

Quenum, F.J.B. and Q. Yan. 2017. Assessing genetic variation and relationships among a mini core germplasm of sesame (Sesamum indicum L.) using biochemical and RAPD markers. Amer. J. Plant Sci. 8:311-327.

Ramegowda, V. and M. Senthil-Kumar. 2015. The interactive effects of simultaneous biotic and abiotic stresses on plants: mechanistic understanding from drought and pathogen combination. J. Plant Physio. 176: 47-54.

Ratnaparkhe, M.B., D.K. Santra, A. Tullu and F.J. Muehlbauer. 1998a. Inheritance of inter-simple-sequence-repeat polymorphisms and linkage with a Fusarium wilt resistance gene in chickpea. Theor. Appl. Gene. 96:348-353.

Ratnaparkhe, M.B., M. Tekeoglu and F.J. Muehlbauer. 1998b. Inter-simple-sequence-repeat (ISSR) polymorphisms are useful for finding markers associated with disease resistance gene clusters. Theor. Appl. Gene. 97: 515-519.

Raza, A., A. Razzaq, S. S. Mehmood, X. Zou, X.Zhang, Y. Lv and J. Xu. 2019. Impact of climate change on crops adaptation and strategies to tackle its outcome: A Review. Plants (Basel). 8: 34.

Rohlf, J.F. 2000. NTSYSpc numerical taxonomy and multivariate analysis system. Version 2.1. Users Guide, Biostatistics Inc., Setauket, New York. 38 p

Salahlou, R., N. Safaie and M. Shams-Bakhsh. 2019. Using ISSR and URP-PCR markers in detecting genetic diversity among Macreophomina phaseolina isolates of sesame in Iran. J. Crop Prot. 8:293-309.

Salme,S.R. and M.I.Cagirgan. 2010. Screening for resistance to Fusarium wilt in induced mutants and world collection of sesame under intensive management. Turkish Journal of Field Crops. 15(1): 89-93

Shabana, R., A.A. Abd El-Mohsen, M. M. A. Khalifa and A. A. Saber. 2014. Quantification of resistance of $F_{6}$ sesame elite lines against Charcoal-rot and Fusarium wilt diseases. Adv. Agric. Biolo. 1: 144-150.

Singh, M., I. Chaudhuri, S.K. Mandal and R.K. Chaudhuri. 2011. Development of RAPD markers linked to Fusarium wilt resistance gene in castor bean (Ricinus communis L.). Gene. Engin. Biotech. J. 28:1-9.

Suja, K.P., T.J. Ohn, S.N. Abraham, A. Thamizh, A.Jayalekshmy and C. Arumughan. 2004. Antioxidant efficacy of sesame cake extract in vegetable oil protection. Food Chem. 84:393-400.

Taghouti, M., N. Nsarellah, F. Gaboun and A. Rochdi. 2017. Multi-environment assessment of the impact of genetic improvement on agronomic performance and on grain quality traits in Moroccan durum wheat varieties of 1949 to 2017. Glo. J. Plant Breed. Gene. 4: 394-404.

Tillman, B.L. and D.W. Gorbet. 2009. Registration of 'AP-4' Peanut. J. Plant Regist. 3:138-142.

Williams,J.G., A.R. Kubelk, K.J. Livak, J.A. Rafalski and S.V.Tingey. 1990. DNA polymorphism amplified by arbitrary primers are useful as genetic markers. Nucl.Acids Res. 18:6531-6535.

Zhang, Y.X., X.R. Zhang, W. Hua, L.H. Wang and Z. Che. 2010. Analysis of genetic diversity among indigenous landraces from sesame (Sesamum indicum L.) core collection in China as revealed by SRAP and SSR markers. Genes and Geno. 32:207-215. 